\title{
TEXT, STRUCTURE, AND COMMON SENSE IN THE INTERPRETATION OF ARTICLE III
}

\author{
MARTIN H. REDISH†
}

\section{INTRODUCTION}

In both the preceding article ${ }^{1}$ and previous work, ${ }^{2}$ Professor Akhil Amar advocates a "two-tier" thesis ${ }^{3}$ as the basis for Congress's power to control federal court jurisdiction pursuant to article III of the Constitution. While finding Justice Story's reliance on article III's mandatory "shall-be-vested" directive ${ }^{4}$ generally persuasive, ${ }^{5}$ Professor Amar rejects Story's conclusion that lower federal courts must exist. ${ }^{6}$ Rather, he believes-in a manner reminiscent of Professor Sager 7 that article III's dictates may be met by the vesting of jurisdiction in either the lower federal courts or the Supreme Court. ${ }^{8}$ More significantly, he limits the mandatory reach of article III's "shall-be-vested" language to only certain categories of cases listed in section 2 of article III. In Professor Amar's words:

[T] he judicial power of the United States must, as an absolute minimum, comprehend the subject matter jurisdiction to decide finally all cases involving federal questions, admiralty, or public ambassadors.... [T] he judicial power may-but need not-extend to cases in the six other, party-defined, jurisdictional categories. The power to decide which of these party-defined cases shall be heard

† Louis and Harriet Ancel Professor of Law and Public Policy, Northwestern University. A.B. 1967, University of Pennsylvania; J.D. 1970, Harvard University.

1 See Amar, The Two-Tiered Structure of the Judiciary Act of 1789, 138 U. PA. L. REv. 1499 (1990).

2 See Amar, A Neo-Federalist View of Article III: Separating The Two Tiers of Federal Jurisdiction, 65 B.U.L. Rev. 205 (1985).

3 See Amar, supra note 1, at 1504-05.

4 Justice Story expounded his theory in Martin v. Hunter's Lessee, 14 U.S. (1 Wheat.) 304, 330 (1816), and in $3 \mathrm{~J}$. Story, Commentaries on the Constitution $\S \S 1584-90$ (1833).

5 See Amar, supra note 2, at 208-09.

6 See id. at 212 (arguing that "Article III plainly imposes no obligation to create lower federal courts"). Actually, Story articulated alternative arguments, one similar to Amar's "two-tier" thesis and one reaching the broader conclusion mandating lower federal courts. See Amar, supra note 1, at 1501-04.

7 See Sager, The Supreme Court, 1980 Term-Foreword: Constitutional Limitations on Congress' Authority to Regulate the Jurisdiction of the Federal Courts, 95 HARv. L. REv. 17, 66 (1981).

8 See Amar, supra note 1, at 1504. 
in Article III courts is given to Congress by virtue of its powers to create and regulate the jurisdiction of lower federal courts, to make exceptions to the Supreme Court's appellate jurisdiction, and to enact all laws necessary and proper for putting the judicial power into effect. ${ }^{9}$

Professor Amar textually premises his dichotomy on the presence of the word "all" as a modifier of the first three categories of cases enumerated in section 2 and its absence in the final six categories. ${ }^{10}$

Professor Amar's theory is troubling in many respects. It ignores article III's unambiguous textual directives and-even under its own construction of that article-presents an internally inconsistent textual interpretation. Moreover, Amar's view of article III is totally devoid of meaningful historical support, and, in fact, is inconsistent with the prevailing understanding of the article's history. This Comment describes the textual, logical, and historical problems with Professor Amar's construction of article III.

9 Amar, supra note 2, at 229-30.

10 See id. at 218-19. Article III provides:

Section 1. The judicial Power of the United States, shall be vested in one supreme Court, and in such inferior Courts as the Congress may from time to time ordain and establish. The Judges, both of the supreme and inferior Courts, shall hold their Offices during good Behavior, and shall, at stated Times, receive for their Services, a Compensation, which shall not be diminished during their Continuance in Office.

Section 2. The judicial Power shall extend to all Cases, in Law and Equity, arising under this Constitution, the Laws of the United States, and Treaties made, or which shall be made, under their Authority;-to all Cases affecting Ambassadors, other public Ministers and Consuls;--to all Cases of admiralty and maritime Jurisdiction;-to Controversies to which the United States shall be a Party; - to Controversies between two or more States;--between a State and Citizens of another State;-between Citizens of different States; - between Citizens of the same State claiming Lands under Grants of different States, and between a State, or the Citizens thereof, and foreign States, Citizens or Subjects.

In all Cases affecting Ambassadors, other public Ministers and Consuls, and those in which a State shall be Party, the supreme Court shall have original Jurisdiction. In all the other Cases before mentioned, the supreme Court shall have appellate Jurisdiction, both as to Law and Fact, with such Exceptions, and under such Regulations as the Congress shall make.

The Trial of all Crimes, except in Cases of Impeachment, shall be by Jury; and such Trial shall be held in the State where the said Crimes shall have been committed; but when not committed within any State, the Trial shall be at such Place or Places as the Congress may by Law have directed.

U.S. Const. art. III, §§ 1-2. 


\section{Distinguishing Between "Textualism" and "Literalism": OF WORDS AND VACUUMS}

\section{A. Focusing on the Words "all" and "shall be vesied": "Selective Literalism" and Article III}

Assume that a new nation, recently freed from colonial bondage, has established itself as a constitutional democracy. Simultaneously recognizing the benefits and dangers of a democratic system, the nation's founders impose outer constraints on popular sovereignty by means of a constitutional structure subject to a difficult, supermajoritarian process of alteration. The founders, also recognizing the simultaneous benefits and dangers of an independent judicial power to enforce those constitutional limits, have included in their constitution the following provision: "All of the judicial power, including the authority to interpret and enforce this constitution, shall be vested in the judiciary, except the legislature may make exceptions to or impose limitation on that authority, as it so desires."

Several years later, the legislature, fearing that the judiciary will over-protect the free speech rights of subversives, thereby threatening national security, enacts a statute providing that "the judiciary may not adjudicate the constitutionality of any legislative limits or penalties imposed upon those deemed by the prosecutor to threaten national security." The following constitutional argument is made by a group challenging the statute: The statute violates the constitution's judicial provision, because use of the words "all" and "shall be vested" in that provision make clear that the judiciary's power to enforce the constitution is both mandatory and total. Should this argument, premised on the provision's text, prevail?

Fortunately, the answer does not rival the difficulty of Lon Fuller's "Grudge Informer"11 or "Speluncean Explorers"12 conundrums. The linguistic argument for an impregnable judicial power quite obviously takes several words totally out of context. By viewing the words "all" and "shall be vested" in a textual vacuum, the argument grossly ignores the text's overall linguistic sense, which clearly was intended to create an overriding legislative power to curb judicial jurisdiction. The response to the argument that such a construction renders meaningless the mandatory nature of the words "all" and "shall be vested" is that those words are not rendered meaningless because they: (1) make clear that the judiciary can exercise this

11 See L. Fuller, The Morality of Law 245-53 (rev. ed. 1969).

12 See Fuller, The Case of the Speluncean Explorers, 62 Harv. L. REv. 616 (1949). 
power, and (2) imply that no other branch of government may exercise the judicial power. In any event, the words are unambiguously modified by the subsequent language empowering the legislature.

Because Professor Amar has committed the very hermeneutical $\sin$ of which he accuses others-the crime of "selective literalism"13 - his suggested construction of article III of our own Constitution, premised on the provision's language, ${ }^{14}$ falls prey to much the same linguistic fallacies as does the argument about the meaning of the hypothetical constitutional provision. To be sure, the language of that provision is not identical to the text of article III. The analogy does make clear, however, that there is nothing magical in the use of the words "all" or "shall be vested"; those words may reasonably be included in a provision that simultaneously vests the legislative branch with substantial authority to curb the very judicial power seemingly vested so completely in the same provision. Thus, if the remainder of article III is properly construed to vest such power in Congress, there exists no linguistic inconsistency with either the inclusive or mandlatory nature of individual words used in the text.

\section{B. Congressional Power to Control Federal Jurisdiction: Examining the Remainder of Article III}

Professor Amar builds his linguistic analysis of article III on a few selected words examined in a vacuum, and then attempts to force the remainder of the provision's language into a Procrustean bed in order to fit his initial assumptions. Close examination of the remaining language, however, makes clear that Professor Amar's distorted interpretation is at odds with any reasonable textual construction, as well as with the intent of those who drafted it.

Article III provides that "[t]he judicial power of the United States, shall be vested in one supreme Court, and in such inferior Courts as the Congress may from time to time ordain and establish."15 This language clearly demonstrates that Congress need not have created lower federal courts in the first place, and the well-documented history of the provision's drafting ${ }^{16}$ _not disputed by

13 See Amar, supra note 1, at 1506.

14 See supra note 10 (for the text of article III).

15 U.S. CONST. art. III, \$1.

16 See P. Bator, D. Meltzer, P. Mishinin \& D. Shapiro, Hart \& Wechsler's The Federal Courts and the Federal System 10-11 (3d ed. 1988) [hereinafter HART \& WEChSLER]. 
Amar $^{17}$ - tends to confirm such a construction. In light of this understanding, the Supreme Court has reasoned that the greater power not to create lower federal courts logically implies the lesser power of creating them with limits on their jurisdiction. ${ }^{18}$

While the Supreme Court's existence was not similarly subjected to congressional discretion, section 2 of article III confines the overwhelming portion of that Court's authority to its appellate jurisdiction, ${ }^{19}$ and gives this jurisdiction "with such exceptions, and under such regulations as the Congress shall make." 20 When read in conjunction with the congressional power over lower federal court jurisdiction granted in section 1 , the inescapable implication of the text is that Congress possesses broad power to curb the jurisdiction of both the lower courts and the Supreme Court.

Professor Amar responds that he is denying neither power to Congress. Rather, he claims that, in regard to the categories of cases to which the judicial power is extended ${ }^{21}$ which are preceded by the word "all," both powers may not be employed simultaneously. ${ }^{22}$ The problem facing his suggested interpretation is, simply, that article III says no such thing. It gives Congress substantial power over each, and fails to prohibit Congress from exercising both powers simultaneously in any category of cases. Had the framers intended the result urged by Professor Amar, they could have said so with considerable ease.

We can see how far Professor Amar's "two-tier" thesis departs from article III's text, viewed as a whole, by imagining what would have happened had Congress chosen to exercise its article III authority-conceded by Professor Amar $^{23}$ — not to create lower federal courts. If no lower federal courts existed, and Congress at some point chose to exercise its authority under the exceptions clause ${ }^{24}$ to

17 See Amar, supra note 1, at 1504 n.10.

18 See Lockerty v. Phillips, 319 U.S. 182, 187 (1943); Sheldon v. Sill, 49 U.S. (8 How.) $441,448-49$ (1850).

19 See U.S. CoNST. art. III, § 2.

$20 \mathrm{Id}$.

21 See id.

22 See Amar, supra note 1, at 1504; Amar, supra note 2, at 229-30.

23 See Amar, supra note 1, at 1504 n.10.

24 See U.S. CoNST. art. III, $\S 2$, cl. 2. I have examined the implications of the exceptions clause in more detail in Redish, Congressional Power to Regulate Supreme Court Appellate Jurisdiction Under the Exceptions Clause: An Internal and External Examination, 27 VILL. L. REv. 900 (1982). Amar criticizes me for "twist[ing] the exceptions language into an implied repeal of unambiguous prior commands," finding this to be "awkward." Amar, Reports of My Death Are Greatly Exaggerated: A Reply, 138 U. PA. L. REv. 1651, 1654 (1990). By definition, however, an "exceptions" clause, while not 
take cases within Amar's first tier out of the Supreme Court's appellate jurisdiction, Professor Amar's thesis breaks down.

Presumably, Professor Amar would conclude that Congress could not make such an exception, because it would result in a total exclusion of federal judicial authority over cases within his first tier, ${ }^{25}$ but, purely as a matter of "holistic" 26 textual analysis, it is difficult to understand the basis for such a conclusion. In effect, Professor Amar would be construing article III to provide: "Congress need not create lower federal courts, and Congress may make exceptions to the Supreme Court's appellate jurisdiction, but if Congress does not create lower courts, it is not permitted to make exceptions to that appellate jurisdiction in certain categories of cases." Obviously, article III says nothing of the sort. It recognizes the possibility that lower courts will not be created, yet simultaneously vests an unencumbered and unconclitional authority in Congress to make exceptions to the Supreme Ciourt's appellate jurisdiction. Thus, Professor Amar has boxed himself into a textual corner, and as a result must ignore the inescapable implications of a synthesis of the provision's two broad congressional powers.

It is here, however, that Professor Amar's reliance on the words "all" and "shall be vested" comes into play. He believes that unless

"an implied repeal," is very much an express modification of what has come previously. That, after all, is the very reason one makes "exceptions" in the first place. While Amar is surely correct in noting the existence of "standard interpretive canons disfavoring repeals by implication." $i d$., it is difficult to imagine something more express than an "exceptions" clause. It is, rather, Amar's own theory that runs afoul of the canon of construction which he cites.

Amar's argument that I have failed to explain why the exceptions clause does not also modify the mandatory original jurisdiction of the Supreme Court, see id. at 1655, is easily disposed of by a simple perusal of article III's text. See supra note 10. Article III, $\S 2$ unqualifiedly vests original jurisdiction in the Court over the specified categories of cases. The exceptions clause, however, quite clearly modifies only the following sentence, concerning soley appellate jurisdiction.

Finally, Amar argues that my reliance on the exceptions clause is incomplete, because "[o]nly the Supreme Court's appellate jurisdiction, not the judicial power of the United States, is . . limited" by the exceptions clause. Amar, supra, at 1654 (emphasis omitted). While this fact is of course true, I fail to understand its significance. The exceptions clause limits only the Supreme Court's appellate jurisdiction, because, simply, it is for the most part not needed to provide congressional power over any other exercise of the judicial power: The Supreme Court's original jurisdiction is narrowly confined in its original grant, and Congress retains power over the jurisdiction of lower federal courts by means of the logic of the Madisonian Compromise.

25 See Amar, supra note 1, at 1503-04.

26 Professor Amar suggests that his construction of article III not only comports with, but is actually dictated by, a "holistic" examination of the text. See id. at 150607. As my analysis has demonstrated, however, the exact opposite is true. 
we read into article III such a limitation on simultaneous usage of the congressional power, the mandatory and all-inclusive nature of those words will be undermined. As already shown in the discussion of the hypothetical constitutional provision, though, there is no reason that use of those words cannot quite reasonably coexist in the same provision with unlimited legislative power to curb jurisdiction. In any event, as we have seen, in attempting to preserve the meaning of a few selected words viewed in a linguistic vacuum, Professor Amar ignores the tenor and scope of considerably more direct and explicit language in the remainder of article III. He is thus similar to the man who places his arm into a cement mixer to recover his hat: $\mathrm{He}$ recovers the hat, but loses his arm.

In addition to its failure to deal adequately with the text's unconditional grant of congressional authority to control federal jurisdiction, Professor Amar's interpretation actually fails to provide a coherent explanation of the very words upon which he places total reliance. Internal contradiction plagues Professor Amar's textual analysis. On the one hand, he premises his conclusion that article III imposes a congressional duty to vest federal jurisdiction in some article III court on the mandatory nature of the words "shall be vested" contained in section 1 and the "shall extend" language in section 2. ${ }^{27}$ Those words, however, precede all of the categories of cases enumerated in section 2.

Logically, then, Professor Amar's emphasis on the use of the word "shall" and its assumed mandatory nature should lead him to conclude-as it did Justice Story-that the mandatory vesting of jurisdiction applies to all categories listed in section 2. As already noted, however, it does not, because of the respective presence and absence of the word "all" before the various categories enumerated in section 2. Yet if the mandatory nature of article III jurisdictionupon which Professor Amar premises his entire theory-derives from use of the word "shall" in section 1, what possible difference does the presence or absence of the word "all" in section 2 make? After all, under Professor Amar's own construction, the words "shall be vested" and "shall extend" establish the compulsory nature of article III jurisdiction, and those words apply to all categories of cases listed in section 2. For under Amar's construction, section 1 dictates that "[t]he judicial Power ... shall be vested" in an article III court, and section 2 extends "[t]he judicial Power" to all of the subsequently listed categories of cases.

27 See supra note 10 (for the text of article III). 
For example, section 2 provides that "the ijudicial Power shall extend ... to Controversies to which the United States shall be a party...." If, as Professor A.mar asserts, the words "shall be vested" in section 1 are to be construed as mandatory, there is no logical way to construe this language not to mandate jurisdiction in some article III court for cases to which the United States is a party, despite the absence of the modifier "all."28 Thus, Professor.Amar cannot have it

28 It should be noted, however, that the one argument that might be thought to lend support to Amar's construction of article III is the fact that the word "all" is used selectively in $\S 2$. Unless one accepts Amar's construction, it is not clear exactly what the word is intended to add when it is used. The answer, I suppose, is that-at least without confirming evidence to the contrary-it is probable that the framers meant nothing by it. Though one might argue that such a construction violates normal canons of interpretation, the remainder of article III actually supports the view that at certain points, not every word was selected with the utmost of thought and care. For example, at certain points $\S 2$ refers to "cases" and at other points to "controversies." Yet the clause vesting the Supreme Court's appellate jurisdiction refers solely to "all the other Cases before mentioned." U.S. ConST. art. III, § 2, cl. 2 (emphasis added). No one, to my knowledge, has suggested that the Supreme Court lacks constitutional authority to review controversies to which the United States shall be a party, simply because article III confines its appellate authority to the review of "all the other Cases before mentioned." In light of the fact that no one at the Convention appears to have either questioned or explained the selective use of the word "all," it is not difficult to believe that it was of no great consequence. In any event, whatever textual awkwardness may arise from ignoring the selective use of the word "all" pales in comparison to the problems of textual analysis caused by the "two-tier" thesis's contorted interpretation of the explicit and unencumbered powers of Congress to control federal jurisdiction. Moreover, Professor Amar's thesis also fails adequately to explain the selective use of the word "all," when synthesized with the "shall be vested" language of $\S 1$.

If one insists that the selective use of the word "all" must have meaning, equally as plausible a construction as that suggested by Amar would be one asserting that the word was employed to mean that the judicial power could reach every case in the categories preceded by the word, while it could not reach an undefined segment of the cases in the remaining categories.

The last legal authority, prior to Amar, to have placed great weight on the selective use of the word "all" was Justice Sutherland in Williams v. United States, 289 U.S. 553, 572-73 (1933). That decision, however, has long been discredited by the Supreme Court. See Glidden Cı. v. Zdanok, 370 U.S. 530, 543, 562-68 (1962). Professor Amar's reliance on the same factor deserves a similar fate. See supra notes 11-15 and accompanying text.

Professor Amar's linguistic obsession with the word "all" in article III is clearly inconsistent with his cavalier treatment of the word "any" in the eleventh amendment. Though by its terms that amendment expressly provides that " $t]$ he judicial power ... shall not be construed to extend to any suit in law or equity, commenced or prosecuted against one of the United States by citizens of another State ...."U.S. ConsT. amend. XI (emphasis added), Amar has argued that the amendment does not bar extension of the judicial power to such suits premised on' federal question jurisdiction. See Amar, Of Sovereignty and Federalism, 96 YaLE L.J. 1425, 1474 (1987); see also Marshall, Fighting the Words of the Eleventh Amendment, 102 HARV. L. REv. 1342 (1989) (critiquing "diversity" theory of eleventh amendment 
both ways: Either the words "shall be vested" in section 1 give rise to mandatory jurisdiction, in which event all categories of cases listed in section 2 must be heard in an article III court (a conclusion Professor Amar rejects), or the words do not give rise to mandatory jurisdiction, in which event none of section 2's jurisdiction is mandatory and Professor Amàr's entire thesis disintegrates. ${ }^{29}$

\section{Adding a "Common Sense" Perspective to the Textual Analysis of Article III}

If one were to attempt to draft a constitutional provision that accomplished the goals of Professor Amar's "two-tier" thesis, the result might be something like this:

Congress may create lower federal courts and make exceptions to the Supreme Court's appellate jurisdiction, but at no time may Congress deny to all federal courts the jurisdiction to adjudicate any case falling within any of the first three categories of cases to which the judicial power has been extended in section 1.

To be sure, alternative phrasings are possible, but it is inconceivable that a rational draftsperson intent on achieving the goals of the "two-tier" thesis would come up with the language actually employed in article III.

construction). Thus, while "all" means "all," apparently "any" does not mean "any." Amar's rather feeble response to this linguistic attack on his eleventh amendment interpretation, see Amar, Marbury, Section 13, and the Original Jurisdiction of the Supreme Court, 56 U. CHI. L. REv. 443, 496-98 (1989), does little to alleviate the problem.

29 Professor Amar might respond that while the words "shall extend" in $\S 2$ are in fact mandatory, their mandatory nature is modified by the selective use of the word "all" in subsequently described categories of cases. The textual problem for his analysis, however, is not the words "shall extend" in $\S 2$, but rather the words "shall be vested" in $\S 1$. It is there stated that the judicial power of the United States "shall be vested." If, as Amar contends, these words are mandatory, then logically every case or controversy falling within the "judicial power" must be heard in some article III court. Thus, absence of the word "all" in front of certain categories of cases enumerated in $\S 2$ is irrelevant, since presumably Professor Amar would not deny that all such cases could be heard in a federal court, and are therefore cases to which the judicial power extends.

One might suggest that such a technical and complex form of textual analysis ignores the broader interpretive function that the judiciary traditionally performs in construing constitutional provisions, and I would agree. In this Comment, I demonstrate that Professor Amar's theory is inconsistent with both the broader sense of the text, see supra notes 15-29 and accompanying text, and the established history of article III. See infra notes 38-49 and accompanying text. However, since Professor Amar makes a narrow, technical textual argument to support his theory, it is appropriate to demonstrate why, even on those terms, his theory is fatally defective. 
To underscore the point, imagine that you, as a founding father of our hypothetical new nation, ${ }^{30}$ have asked a constitutional expert to draft a constitutional provision implementing the "two-tier" thesis, and in response she provides you a draft identical to the text of article III. It would, no doubt, be reasonable to ask her how the chosen language actually accomplishes its goal. Presumably, the expert-a disciple of Professor Amar's school of textual construction-would respond: "That should be clear. I have carefully inserted the word 'all' in front of the three categories which you deemed most important and which you therefore wanted shielded from legislative preemption." In such an event, you would have a clear right to request a return of the consultant's fee you paid for the drafting. The "expert" would have included language explicitly vesting broad, seemingly unlimited authority in Congress to control the jurisdiction of both the lower courts and the Supreme Court, and included as the only textual assurance that these powers would not be plenary the selective-and cryptic-use of the word "all."

What Professor Amar is asking us to believe is that the men who drafted the Constitution, members of one of the most intellectually powerful groups of political leaders in American history, came up with the language of article III as a means of constitutionalizing his "two-tier" thesis. As a textual matter, such a conclusion is, to say the least, counter-intuitive. But increasing the unlikeliness of this historical scenario is the complete absence of any contemporaneous debate or commentary expressing the intent to adopt the "two-tier" thesis by adopting article III. ${ }^{31}$ Thus, even conceding that article III's language is somehow capable of a construction consistent with

30 See supra text preceding note 11 .

31 In terms of contemporaneous legislative history, Professor Amar concedes the absence of a "smoking gun" at the time of the Convention, but contends that the text of article III is a sufficient "smoking gun" in and of itself. See Amar, supra note 1, at 1565-66. My critique of his tortured textual analysis should provide a sufficient basis on which to refute that proposition.

Failing to find contemporaneous support, Amar is forced to find it in after-thefact assertions of Justices Story and Marshall. See id. at 1513-14. But Amar's reliance on Story carries little weight, since Story also argued for the required existence of lower federal courts, a proposition Amar rejects. See id. at $1504 \mathrm{n}$.10. If Story fails to constitute dispositive authority for the latter proposition, I fail to understand how he does so for Amar's theory. Marshall, on the other hand, is noted both for his strongly held pro-federal political views and his opinions usurping power for the federal government, despite questionable consistency with constitutional text. See, e.g., Osborn v. Bank of the United States, 22 U.S. (9 Wheat.) 738, 818-28 (1824) (giving a virtually unlimited interpretation to article III's "arising under" jurisdiction); McCulloch v. Maryland, 17 U.S. (4 Wheat.) 316, 411-22 (1819) (giving virtually unlimited power to Congress to invoke the necessary-and-proper clause). 
the "two-tier" thesis, ${ }^{32}$ Professor Amar would have us believe that the framers all understood that the mysterious selective insertion of the word "all" was consciously designed to achieve this end, despite the apparent failure of any of them ever to even ask the reason for the selective use of the word "all," much less to articulate the "two-tier" thesis as an explanation. When one adds this complete absence of supporting contemporaneous commentary to the tortured textual construction required to reach Professor Amar's thesis in the first place, ${ }^{33}$ rejection of that thesis, on grounds of both textual analysis and common sense, becomes inescapable.

\section{Constitutional Structure and the Role OF THE FEDERAL Judiciary}

Professor Amar has argued consistently that his "two-tier" thesis rests on more than merely a neutral construction of constitutional text. ${ }^{34}$ In addition, he believes that, wholly apart from its wording, article III must be construed to adopt the "two-tier" thesis, lest the federal judiciary be removed from the adjudication of cases in which its unique expertise is required. ${ }^{35}$ In reaching this conclusion, he rejects the notion that state and federal courts are fungible in such cases. $^{36} \mathrm{He}$ has argued that

[t]he reasons for not trusting Congress to police the states are mirrored by symmetrical reasons for not trusting state court judges to police Congress. In many cases, the interests of such courts and Congress would not be truly adverse. Both were likely to be too closely tied to state legislatures and excessively vulnerable to parochial and political pressures. ${ }^{37}$

Professor Amar, though, has missed the point of the historical

Thus, Amar's reliance on Marshall as a basis for proving the intent of the framers is akin to relying on a testimonial by Richard Nixon to prove one's honesty.

Finally, Amar points to the Judiciary Act of 1789 to demonstrate the framers' intent. See Amar, supra note 1, at 1515-41. However, that the Act may have complied with Amar's "two-tier" thesis actually proves nothing as to the framers' understanding of the constitutional limits on congressional power to control federal jurisdiction. That Congress chose to vest jurisdiction somewhere in the federal judiciary is wholly irrelevant to the question of whether the Constitution was intended to require Congress to reach this result.

32 But see supra notes 23-29 and accompanying text.

33 See supra note 31 and accompanying text.

34 See Amar, supra note 1, at 1566; Amar, supra note 2, at 229-30.

35 See Amar, supra note 2, at 229-30.

36 See Amar, supra note 1, at 1509.

37 Amar, supra note 2, at 226-27 (footnote omitted). 
inquiry. The issue is not whether, purely as a policy matter, his critique of congressional reliance on state courts is unwise. Indeed, purely on the level of social and legal policy, I am in total agreernent with his critique. ${ }^{38}$ The issue, rather, is whether the framers accepted it. Surely, it is not inconceivable that at least a significant portion of the framers did not. After all, the modern Supreme Court has often rejected all attacks on the parity of state and federal judges. ${ }^{39}$ Why, then, is it so difficult for Professor Amar to accept that a number of the framers would also reject such attacks?

Underscoring the likelihood that many framers accepted judicial parity is the fact that Congress chose not to provide for general federal question jurisdiction in the lower federal courts until $1875,{ }^{40}$ well after the Civil War. While it is true that review in the Supreme Court was generally available, this point nevertheless demonstrates that the initial Congress-including a large number of framers-did not sufficiently accept Maclison's strong distrust of state judges to accept his conclusion that lower federal courts should receive primary responsibility for adjudication of federal law and protection of federal rights.

The fact that, in Professor Amar's words, "[t]o have expected Congress alone to police state legislators . . . would be to have expected a political and (predictably) parochial sentry to guard the vault of constitutional rights from political and parochial state legislators" 41 does not necessarily imply that the framers disapproved. In fact, the likely political influence of the states over Congress was to many a strong attraction of the constitutional system. As Madison himself wrote:

As a security of the rights \& powers of the States in their individual capacities, ag[ainst] an undue preponderance of the powers granted to the Government over them in their united capacity, the Constitution has relied on.... [t]he responsibility of the Senators

38 I have long resisted the claim that parity exists between state and federal courts as interpreters and enforcers of federal rights. See Redish, Judicial Parity, Litigant Choice, and Democratic Theory: A Comment on Federal Jurisdiction and Constitutional Rights, 36 UCLA L. REv. 329, 331-38 (1988); Redish, The Doctrine of Younger v. Harris: Deference in Search of a Rationale, 63 CoRnell. L. Rev. 463, 482-84 (1978).

39 See, e.g., Younger v. Harris, 401 U.S. 37, 49 (1971) (noting that a state court affords an adequate opportunity to raise constitutional claims).

40 See Judiciary Act of 1875 , ch. 137, 18 Stat. 470; see also HART \& WECHSLER, supra note 16 , at $960-63$ (discussing the history of federal question jurisdiction).

41 Amar, supra note 2, at 225. 
and Representatives in the Legislature of the U.S. to the Legislatures \& people of the States. ${ }^{42}$

Puzzlingly, Professor Amar has relied on the fact that "the Constitutional Convention explicitly rejected both congressional and executive 'negatives' over state laws in favor of judicial review by the federal courts"43 to support his position that the framers would not have left ultimate control over the states in Congress. Actually, this historical fact tends to support the exact opposite view. Nothing in this rejection of a "negative" power, of course, precluded Congress from still preempting state law by enactment of substantive legislation. Thus, the practical effect of the Convention's rejection of a congressional power to negate state law was to make congressional supervision of the states that much more difficult. With the negative, Congress could simply have overturned state law; without it, Congress would have to take the further step of enacting affirmative substantive legislation. Rejection of the congressional negative, then, grew out of fear that the federal government would too freely exercise supervision of the states. Rather than representing a fear of too little federal supervision of the states, this decision represented a fear of too much supervision.

The argument of several framers that a judicial check was adequate ${ }^{44}$ simply meant that Congress need not perform the checking function itself, but could, if it chose, delegate the power to enforce federal supremacy to the federal courts. The exercise of federal judicial policing of the states was seen as a means of enforcing congressional intent, not as a means of superseding congressional authority. ${ }^{45}$

429 The Writings of James Madison 338, 395-96 (G. Hunt, ed. 1910) (reprinting Letter from James Madison to Edward Everett (Aug. 28, 1830)).

43 Amar, supra note 2, at 223 (footnote omitted).

44 See id. at 248.

45 It is important to note that most of the arguments made in support of the creation of lower federal courts focused on the need to empower Congress to employ the federal courts to police the states, not to require Congress to do so. See Redish, Constitutional Limitations on Congressional Power to Control Federal Jurisdiction: A Reaction to Professor Sager, 77 Nw. U.L. REv. 143, 151-53 (1982).

Professor Amar rejects my previously-made arguments that it is unlikely that the framers were substantially concerned with state violations of constitutional rights because of the inclusion of precious few limitations on state authority, by pointing to the Constitution's prohibition of state authority to enact bills of attainder or ex post facto laws. See U.S. CoNST. art. I, § 10, cl. 1; Amar, supra note 2, at 225, 247 n.134. The fact remains, however, that on the whole, the framers contemplated very few such limitations.

In any event, Professor Amar's argument begs the historical question. If many of the framers believed in judicial parity, they would not have been bothered by 
Professor Amar has asserted that "[w]ith respect to cases arising under the Constitution, the need for mandatory jurisdiction of the national judiciary was manifest." 46 In support, he relies on arguments articulated by Madison, ${ }^{47}$ but this reliance underscores the overly simplistic and superficial nature of Professor Amar's approach to interpretation of legislative intent. His analysis fallaciously views the framers as a monolithic group. The reality, however, was very different, as evidenced by a simple fact that Professor Amar ignores: Madison lost the battle over the shaping of article III. Though he had argued vigorously for the mandatory creation of lower federal courts, he was fought to a stalemate by the equally vigorous advocates of states' rights-for example, Rutledge of South Carolina and Sherman of Connecticut. ${ }^{48}$

Madison was forced to retreat considerably from his original position and to fashion his famed compromise. Thus, it is all but inconceivable that the many states rights' advocates, who opposed even allowing the creation of lower federal courts, would have concurred in Professor Amar's critique of the reliance on state courts in constitutional cases. ${ }^{49}$ Professor Amar has simply assumed that the

reliance on state courts in such cases. As already noted, the modern Supreme Court's reliance on state courts to act as adjudicators of federal constitutional rights against state action-with only a statistically minimal chance of Supreme Court review-reflects an assumption of state-federal court parity. Indeed, the Court's conclusion was reached long after the dramatic change in the political theory of federalism caused by the Civil War and the post Civil War amendments. Surely, then, it is not so unreasonable to believe that many of the framers would have reached a similar conclusion at a lime when the belief in the need to protect state interests was at the peak of its acceptance. The fact that both Professor Amar and I today reject such a conclusion as a policy matter does not mean that the framers also rejected it.

46 Amar, supra note 2, at $246-47$ (footnote omitted).

47 See id. at 247 n.134.

48 See Redish \& Woods, Congressional Power to Control the Jurisdiction of Lower Federal Courts: A Critical Review and a New Synthesis, 124 U. PA. L. REv. 45, 52-55 (1975).

49 Professor Amar correctly notes that John Rutledge, an opponent of lower federal courts, argued that "[t]he state Tribunals [are most proper] in all cases to decide in the first instance[,] the right to appeal to the supreme national tribunal being sufficient to secure the national rights \& uniformity of Judgmnts." See Amar, supra note 2, at 249 (quoting 1 The Records of the Federal Convention of 1787 124 (M. Farrand ed. 1911)). But surely the comment of one framer, while speaking about a totally distinct provision, provides an insufficient basis on which to overcome the unambiguous language of the exceptions clause vesting in Congress unlimited authority to make exceptions to the Supreme Court's appellate jurisdiction.

In any event, it is arguable that, when viewed in context, Rutledge's comment is fully consistent with the broad language of the exceptions clause. Recall that much of the argument in favor of the vesting of federal question jurisdiction in the federal judiciary was to empower Congress to employ the federal judiciary to police the states. 
framers must have agreed with his critique of reliance on state courts. Fortunately or unfortunately, however, an academic's normative view and the realities of history are often not coterminous.

Professor Amar has contended that under my own suggested construction of article III, ${ }^{50}$ "[ $\left.t\right]$ he 'shall' language . . . apparently falls in [sic] an interpretive blind spot," and he therefore finds an "obvious tension between the clear words of Article III"51 and my construction. As already noted, ${ }^{52}$ though, Professor Amar's construction of article III also ignores what he finds to be the natural meaning of the "shall be vested" language. He refuses to impose on Congress a mandatory obligation to vest in the federal judiciary all of the categories of cases enumerated in section 2, even though the "shall be vested" language of section 1 draws no distinctions among categories of cases to which the "judicial power" extends in section 2.

Moreover, it is actually Professor Amar who inserts the explicit language of article III into an interpretive "blind spot." For the arguably mandatory nature of the "shall be vested" language cannot legitimately be construed in a textual vacuum. Rather, it must be analyzed in conjunction with the remainder of article III. So construed, the "shall be vested" language is explicitly qualified by both the clear discretion of Congress not to create lower federal courts in section 1 and the equally clear (and unlimited) congressional authority to make exceptions to the Supreme Court's appellate jurisdiction. Thus, it is actually Professor Amar's analysis which runs directly counter to the explicit textual dictates of article III.

\section{Conclusion: Adding the Due Process Factor}

Professor Amar's "two-tier" construction of article III fails to meet its burden of production because of a lack of either textual or contemporaneous historical support. On the textual level, his thesis

Rutledge's comment concerning the availability of Supreme Court review could reasonably be viewed as a response to those arguing for lower federal courts as a necessary means of enabling Congress to employ the federal judiciary as an enforcer. According to this reading, Rutledge would be arguing that the existence of lower federal courts should be prohibited, and that Congress' interest in having available an adequate federal judicial enforcer, if it so desired, would be satisfied by the existence of the Supreme Court. Under such a construction of Rutledge's statement, it is in no way inconsistent with the vesting of broad power in Congress to control the jurisdiction of both lower federal courts and the Supreme Court.

50 See supra notes 19-22 and accompanying text.

51 Amar, supra note 2, at 229.

52 See supra notes 27-29 and accompanying text. 
ignores the broad power of Congress to regulate the jurisdiction of both the lower courts and the Supreme Court-powers in no way rendered mutually exclusive of each other by the text of article III. On the level of historical intent, Professor Amar points to no contemporaneous statements by the framers evincing an understanding that they intended to adopt the "two-tier" thesis as the premise for article III. Finally, Professor Amar's arguments grounded in constitutional structure fallaciously equate the views of some framers with those of the entire group, and the values of twentieth century law professors with those of the framers.

It does not necessarily follow, however, that absolutely no limits exist on Congress's authority to preclude federal court jurisdiction in at least certain types of cases. The due process clause ${ }^{53}$ of course supersedes any contrary language contained in the body of the Constitution. ${ }^{54}$ Although the Supreme Court has never spoken definitively on the issue, the lower federal courts appear to agree that a total preclusion of judicial review by Congress when constitutional rights are at stake would violate due process. ${ }^{55}$ These decisions, however, do not support such a conclusion when all that Congress has done is to preclude federal court jurisdiction. In the past, I have argued that in cases challenging the constitutionality of state action,

53 U.S. Const. amend. V.

54 Professor Amar contends that my view that article III cannot rationally be construed in such a way so as to ignore its clear directives vesting in Congress authority to make exceptions to the Supreme Court's appellate jurisdiction and discretion not to create lower federal courts, see supra notes 19-22 and accompanying text, is inconsistent with recognition of a possible due process limitation on such congressional authority: "Redish's mistake is in focusing solely on the limiting language of the due process clause and ignoring the limiting language of Article III itself." Amar, supra note 2, at 229 n.84. But Professor Amar has completely missed the point that the entire purpose of an amendment is to amend-or "alter"-something in the existing Constitution. Thus, there is nothing illogical in suggesting the possibility of an inconsistency between the dictate of an amendment on the one hand and a directive contained in the text on the other hand. This is a far cry, however, from construing certain language in a constitutional provision to contradict an explicit, unqualified directive contained subsequently in the very same provision. While one naturally expects an amendment to contradict or limit powers described in the text-indeed, otherwise there would often be no need for the amendment in the first place-it makes little sense to assurne that textual language is designed to contradict an explicit, unlimited authorization. later in the very same provision.

55 See, e.g., Bartlett v. Bowen, 816 F.2d 695, 703 (D.C. Cir. 1987) (finding that a statute that precludes both state and federal judicial review of its constitutionality would be an unconstitutional infringement of due process); Battaglia v. General Motors Corp., 169 F.2d 254, 257 (2d Cir.), cert. denied, 335 U.S. 887 (1948) (noting due process restrictions on Congress's power to give, withhold, and restrict the jurisdiction of the courts). 
the state courts do not constitute an adequate forum for due process purposes, because they are not sufficiently insulated from potential state pressure. They therefore fail to provide the truly independent adjudication required by due process. ${ }^{56}$

Admittedly, the due process theory fails to achieve all of the policy goals attained by acceptance of Professor Amar's "two-tier" thesis. ${ }^{57}$ However, while I can sympathize with the underlying policy goals of Professor Amar and others who have fashioned similarly questionable constructions of article III, ${ }^{58}$ ultimately such wholly result-oriented, unsupported interpretations do a disservice to the enterprise of constitutional interpretation.

56 See Redish \& Marshall, Adjudicatory Independence and the Values of Procedural Due Process, 95 Yale L.J. 455, $496-97$ (1986). Puzzlingly, Professor Amar characterizes my argument as a "newly-voiced position." Amar, supra note 24, at 1654 n.18. However, Professor Amar attacked that very position of mine some five years ago. See supra note 54 .

57 See supra notes $34-37$ and accompanying text.

58 See generally Sager, supra note 7. 
